\title{
Comparison of perinatal outcome in twin pregnancy with and without cervical cerclage
}

\author{
Mitesh Suresh Chavan*, Mehernosh Jamshed Jassawalla
}

Nowrosjee Wadia Maternity Hospital, Mumbai, Maharashtra, India

Received: 31 August 2016

Accepted: 28 September 2016

\section{*Correspondence:}

Dr. Mitesh Suresh Chavan,

E-mail: mitschavan004@gmail.com

Copyright: (c) the author(s), publisher and licensee Medip Academy. This is an open-access article distributed under the terms of the Creative Commons Attribution Non-Commercial License, which permits unrestricted non-commercial use, distribution, and reproduction in any medium, provided the original work is properly cited.

\section{ABSTRACT}

Background: The incidence of multifetal pregnancies has registered increase globally. Babies born from multiplebirth pregnancies are much more likely to result in premature birth than those from single pregnancies. Knowledge of role of cervical cerclage in preventing preterm birth especially in twin pregnancy can be helpful to prevent complication related to preterm birth and ultimately of low birth weight babies.

Methods: Depending upon who opt for the procedure 100 patients were divided equally into two groups: 1)Twin pregnancy with cervical cerclage; 2)Twin pregnancy without cervical cerclage. We measured maternal outcomes which include time for which patient required to be hospitalized, maternal pyrexia, cervical or bladder injury and other maternal morbidity and perinatal outcomes which include preterm delivery (delivery before 37 completed weeks), low birth weight (birth weight $\leq 2000 \mathrm{~g}$ ), IUGR, perinatal mortality, indicators of perinatal morbidity (APGAR scores and neonatal unit admission), stillbirth, second trimester loss and presence of congenital malformations.

Results: In Study group 22\% delivered before 34 weeks of gestation, $46 \%$ delivered between 34 and 37 weeks of gestation, $32 \%$ delivered after 37 weeks of gestation compared to 44\%, 48\% and $8 \%$ respectively in Control group. The mean gestational age at delivery was 35.3 weeks in Study group and was 33.2 weeks in Control group. In study group $47 \%$ neonates had birth weight less than $2 \mathrm{Kg}$ and in Control group $69 \%$ neonates had birth weight less than $2 \mathrm{Kg}$. In Study group 95\% had Apgar score more than 6 whereas in Control group $86 \%$ had APGAR score more than 6. The mean APGAR for Study group was 8.5 and for Control group was 7.5. $45 \%$ neonates had complications in Study group whereas $67 \%$ neonates in Control group. Overall Low birth weight was most common complications in both the groups. Respiratory distress was more common in Control group.

Conclusions: In spite of close vigilance, preterm birth in twin gestation is common and unpredictable. It is difficult to predict those who may require cervical cerclage although all multiple pregnancies are at high risk. Cerclage should be considered an option for patients with twin pregnancies in the second trimester to prolong the duration of gestation as close to term as possible.

Keywords: Cerclage, Preterm, Twins

\section{INTRODUCTION}

The incidence of multifetal pregnancies has registered increase globally. This is partly due to the widespread use of ovulation induction drugs in the treatment of infertility, assisted reproductive technology and also due to delaying childbearing to a later age.
With the development of ultrasound techniques, it has become apparent that incidences of multiple gestations are more common than previously indicated which can be done as early as 6-7 weeks of gestation.

Babies born from multiple-birth pregnancies are much more likely to result in premature birth than those from 
single pregnancies. $51 \%$ of twins and $91 \%$ of triplets are born preterm, compared to $9.4 \%$ in singletons. ${ }^{1} 14 \%$ of twins and $41 \%$ of triplets are even born very preterm, compared to $1.7 \%$ in singletons. ${ }^{1}$ The preterm births in multiples tending to have a lower birth weight which ultimately leads to hypothermia, respiratory difficulties, PDA, intracranial bleeding, hypoglycemia, necrotizing enterocolitis, infection, ROP and death. ${ }^{2-5}$ Preterm birth is leading cause of neonatal death and India being with greatest number of preterm births. ${ }^{6}$

The probable reasons for preterm birth are overdistention of uterus and intrauterine infection ${ }^{7}$ which may be because of early opening of cervix and exposure of fetal membranes to the bacterial flora of vagina. ${ }^{8}$ Also the risk of preterm birth is inversely proportion to the cervical length. ${ }^{9}$

Cervical cerclage (tracheloplasty), also known as a cervical stitch, is used for the treatment of cervical incompetence (or insufficiency), a condition where the cervix has become slightly open or closed with short in length. ${ }^{10}$ Use of cerclage include the management of women considered to be at high risk of mid-trimester loss and spontaneous preterm birth by virtue of factors such as multiple pregnancy, uterine anomalies, a history of cervical trauma and cervical shortening seen on sonographic examination. While cerclage may provide a degree of structural support to a 'weak' cervix, its role in maintaining the cervical length and the endocervical mucus plug as a mechanical barrier to ascending infection may be more important.

This study was for knowledge of role of cervical cerclage in preventing preterm birth especially in multifetal gestation to prevent complication related to preterm birth and ultimately of low birth weight babies with their poor perinatal outcome.

\section{METHODS}

This was a prospective observational study in the department of obstetrics and gynaecology at Tertiary care centre hospital, Mumbai, Maharashtra, India.

\section{Inclusion criteria}

All women presenting with viable twin pregnancy between 16 and 22 weeks of gestation

\section{Exclusion criteria}

All women with twin pregnancy presenting with

- $\quad$ Bleeding per vaginum

- Already proven upper genital infection or chorioamnionitis

- PPROM (Preterm Premature Rupture Of Membranes)

- IUFD (Intrauterine Fetal Death)
- Malformed foetus

- Uterine anomalies

- Threatened preterm

- Low lying placenta

- Pre-existing maternal medical illness like cardiovascular, pulmonary, renal, hepatic and endocrine disease.

\section{Study procedure}

- 100 women selected who fit in the above mentioned criteria.

- Baseline data was recorded by questionnaire and patient interview.

- Once the patient enrolled herself in the study, an ultrasonography was done as routine procedure for fetal wellbeing.

- All the patients with twin pregnancy registered in antenatal OPD between 16-22 weeks of gestation were explained the necessity of cerclage.

- Depending upon who opt for the procedure patients were divided into two groups

- Study group $\rightarrow$ Twin pregnancy with cervical cerclage.

○ Control group $\rightarrow$ Twin pregnancy without cervical cerclage.

- All the patients were subjected to standardized form of management.

- Any incident such as IUGR (Intra Uterine Growth Retardation), IUFD (Intra uterine Fetal demise), LBW (Low birth weight), PROM (Premature rupture of membranes), bleeding, bladder or cervical injury, maternal pyrexia, etc was recorded.

- Potential confounding factors were identified and adjustment was made in statistical models. These factors include maternal age, gravidity, gestational diabetes, gestational hypertension, sepsis.

- The following adverse pregnancy outcomes among the two groups will then be compared: Second trimester loss, IUGR, preterm labor (labor $<37$ weeks of gestation), PPROM (membrane rupture $<37$ weeks of gestation), Stillbirth, death following live birth, discordant growth (difference between weight of twins >20\%), congenital anomaly, twin-twin transfusion

\section{End point}

- The end point of the study was achieved with the delivery of the baby and its course till discharge from the hospital

- Any patient not willing for further participation in the study at any time could withdraw.

\section{Outcome measures}

- Maternal outcome 
- Maternal pyrexia

○ Cervical or bladder injury

- Other maternal morbidity

- Time for which patient required to be hospitalized

- $\quad$ Outcome of the pregnancy
○ Onset of Labour
- Gestational age at the time of delivery
○ Mode of delivery

- Neonatal outcome

○ Preterm delivery (delivery before 37 completed weeks)

○ Low birth weight (birth weight $\leq 2500$ g)

○ IUGR (Intrauterine Growth Retardation)

○ Perinatal mortality

○ Perinatal morbidity

- APGAR scores

- Neonatal unit admission

- Stillbirth

- Second trimester loss

- Presence of congenital malformations

\section{Statistical analysis}

The results were expressed as Mean +/_ SD and Proportion (\%).

Statistical tests used were Chi square test, Fischer's exact test.

\section{RESULTS}

Table 1: Association of weeks of gestation at delivery among study group and control group.

\begin{tabular}{|lllll|}
\hline $\begin{array}{l}\text { Weeks at } \\
\text { delivery }\end{array}$ & & Yes & No & \\
\cline { 1 - 1 } $\begin{array}{l}\text { Before } 34 \\
\text { Wks }\end{array}$ & Count & 11 & 22 & 33 \\
\hline & $\%$ & $22.0 \%$ & $44.0 \%$ & $33.0 \%$ \\
\hline $\begin{array}{l}34 \text { to } 37 \\
\text { Wks }\end{array}$ & Count & 23 & 24 & 47 \\
\hline & $\%$ & $46.0 \%$ & $48.0 \%$ & $47.0 \%$ \\
\hline After 37 Wks & Count & 16 & 4 & 20 \\
\hline & $\%$ & $32.0 \%$ & $8.0 \%$ & $20.0 \%$ \\
\hline Total & Count & 50 & 50 & 100 \\
\hline & $\%$ & $100 \%$ & $100 \%$ & $100 \%$ \\
\hline $\begin{array}{l}\text { Chi-square } \\
\text { test }\end{array}$ & Value & df & P value & \\
\cline { 1 - 3 } $\begin{array}{l}\text { Pearson } \\
\text { Chi-Square }\end{array}$ & 10.888 & 2 & 0.004 & Significant \\
\hline
\end{tabular}

Table 1 shows association of weeks of gestation at delivery between two groups. Number of women who were undergone cerclage and delivering after 37 weeks were significantly high. (Statistically significant $\mathrm{p}=0.004)$.

Table 2: Association of mode of delivery among study group and control group.

\begin{tabular}{|c|c|c|c|c|}
\hline \multirow{2}{*}{ Mode of delivery } & & \multicolumn{2}{|c|}{ Cerclage } & \multirow{2}{*}{ Total } \\
\hline & & Yes & No & \\
\hline \multirow[t]{2}{*}{ Elective LSCS } & Count & 14 & 4 & 18 \\
\hline & $\%$ & $28 \%$ & $8.0 \%$ & $18.0 \%$ \\
\hline \multirow[t]{2}{*}{ Emergency LSCS } & Count & 29 & 32 & 61 \\
\hline & $\%$ & $58 \%$ & $64 \%$ & $61 \%$ \\
\hline \multirow[t]{2}{*}{$\begin{array}{l}\text { Full term vaginal } \\
\text { delivery }\end{array}$} & Count & 1 & 1 & 2 \\
\hline & $\%$ & $2.0 \%$ & $2.0 \%$ & $2.0 \%$ \\
\hline \multirow[t]{2}{*}{$\begin{array}{l}\text { Preterm vaginal } \\
\text { delivery }\end{array}$} & Count & 6 & 13 & 19 \\
\hline & $\%$ & $12 \%$ & $26 \%$ & $19 \%$ \\
\hline \multirow[t]{2}{*}{ Total } & Count & 50 & 50 & 100 \\
\hline & $\%$ & $100 \%$ & $100 \%$ & $100 \%$ \\
\hline Chi-Square test & Value & $\mathrm{df}$ & $\begin{array}{l}P \\
\text { value }\end{array}$ & \multirow{2}{*}{ Significant } \\
\hline $\begin{array}{l}\text { Pearson Chi- } \\
\text { square }\end{array}$ & 8.282 & 3 & 0.041 & \\
\hline
\end{tabular}

Table 2 shows association of mode of delivery between two groups.

Number of women who were undergone cerclage and had elective LSCS were 14 and preterm vaginal delivery 6 compared to 4 and 13 that of not undergoing cerclage respectively (Statistically significant $\mathrm{p}=0.041$ ).

Table 3: Association of APGAR of neonates among study group and control group.

\begin{tabular}{|llccc|}
\hline \multirow{2}{*}{ A pgar } & \multicolumn{4}{c}{ Cerclage } \\
Less than 7 & Count & 5 & 14 & 19 \\
\hline & $\%$ & $5.0 \%$ & $14.0 \%$ & $9.5 \%$ \\
\hline 7 and above & Count & 95 & 86 & 181 \\
\hline & $\%$ & $95 \%$ & $86.0 \%$ & $90.5 \%$ \\
\hline Total & Count & 100 & 100 & 200 \\
\hline & $\%$ & $100 \%$ & $100 \%$ & $100.0 \%$ \\
\hline Chi-Square test & Value & df & P & \\
\cline { 1 - 4 } & 4.710 & 1 & 0.029 & Significant \\
\hline $\begin{array}{l}\text { Pearson Chi- } \\
\text { square }\end{array}$ & & & & \\
\hline
\end{tabular}

Table 3 shows association of Apgar score of Neonates at 5 minutes of two groups.

There were 14 neonates whose Apgar score was less than 7 and their mother were not undergone cerclage compare to 5 neonates that of undergoing cerclage (Statistically significant $\mathrm{p}=0.029$ ). 
Table 4: Association of birth weight of neonates among study group and control group.

\begin{tabular}{|c|c|c|c|c|}
\hline \multirow{2}{*}{ Birth weight } & & \multicolumn{2}{|c|}{ Cerclage } & \multirow{2}{*}{ Total } \\
\hline & & Yes & No & \\
\hline \multirow[t]{2}{*}{ Up to $1 \mathrm{Kg}$} & Count & 5 & 16 & 21 \\
\hline & $\%$ & $5.0 \%$ & $16.0 \%$ & $10.5 \%$ \\
\hline \multirow[t]{2}{*}{1.001 to 1.5} & Count & 12 & 27 & 39 \\
\hline & $\%$ & $12 \%$ & $27.0 \%$ & $19.5 \%$ \\
\hline \multirow[t]{2}{*}{1.501 to $2 \mathrm{Kg}$} & Count & 30 & 26 & 56 \\
\hline & $\%$ & $30 \%$ & $26.0 \%$ & $28.0 \%$ \\
\hline \multirow[t]{2}{*}{2.001 to $2.5 \mathrm{Kg}$} & Count & 40 & 27 & 67 \\
\hline & $\%$ & $40 \%$ & $27.0 \%$ & $33.5 \%$ \\
\hline \multirow[t]{2}{*}{$>2.5 \mathrm{Kg}$} & Count & 13 & 4 & 17 \\
\hline & $\%$ & $13 \%$ & $4.0 \%$ & $8.5 \%$ \\
\hline \multirow[t]{2}{*}{ Total } & Count & 100 & 100 & 200 \\
\hline & $\%$ & $100 \%$ & $100 \%$ & $100.0 \%$ \\
\hline Chi-Square test & Value & df & $\begin{array}{l}\mathrm{P} \\
\text { value }\end{array}$ & \multirow{2}{*}{ Significant } \\
\hline $\begin{array}{l}\text { Pearson Chi- } \\
\text { square }\end{array}$ & 19.410 & 4 & 0.007 & \\
\hline
\end{tabular}

Table 4 shows association of birth weight of neonates between two groups.

The mother who were undergone cerclage, there were 13 neonates whose birth weight was more than $2.5 \mathrm{Kg}$ and 5 neonates whose birth weight was less than $1 \mathrm{Kg}$ compare to 4 and 16 neonates respectively of those who were not undergone cerclage (Statistically significant $\mathrm{p}=0.007$ ).

Table 5: Association of number of neonates requiring NICU admission among study group and control group.

\begin{tabular}{|c|c|c|c|c|}
\hline \multirow{2}{*}{ NICU admission } & & \multicolumn{2}{|c|}{ Cerclage } & \multirow{2}{*}{ Total } \\
\hline & & Yes & No & \\
\hline \multirow[t]{2}{*}{ Yes } & 40 & 56 & 96 & 40 \\
\hline & $40.0 \%$ & $56 \%$ & $48.0 \%$ & $40.0 \%$ \\
\hline \multirow[t]{2}{*}{ No } & 59 & 39 & 98 & 59 \\
\hline & $59.0 \%$ & $39 \%$ & $49.0 \%$ & $59.0 \%$ \\
\hline \multirow[t]{2}{*}{ NA } & 1 & 5 & 6 & 1 \\
\hline & $1.0 \%$ & $5.0 \%$ & $3.0 \%$ & $1.0 \%$ \\
\hline \multirow[t]{2}{*}{ Total } & 100 & 100 & 200 & 100 \\
\hline & $100 \%$ & $100 \%$ & $100 \%$ & $100.0 \%$ \\
\hline Chi-Square test & Value & $\mathrm{df}$ & $\begin{array}{l}\mathrm{P} \\
\text { value }\end{array}$ & \multirow{2}{*}{ Significant } \\
\hline $\begin{array}{l}\text { Pearson Chi- } \\
\text { square }\end{array}$ & 9.410 & 2 & 0.009 & \\
\hline
\end{tabular}

Table 5 shows association of neonates requiring NICU admission between 2 groups.

The mother who were not undergone cerclage, there were 56 neonates who required NICU admission compare to 40 neonates of those who were undergone cerclage (Statistically significant $\mathrm{p}=0.009$ ).
Table 6: Association of duration of stay in NICU of neonates among study group and control group.

\begin{tabular}{|c|c|c|c|c|}
\hline \multirow{2}{*}{$\begin{array}{l}\text { NICU stay (if } \\
\text { any) }\end{array}$} & & \multicolumn{2}{|c|}{ Cerclage } & \multirow{2}{*}{ Total } \\
\hline & & Yes & No & \\
\hline \multirow[t]{2}{*}{ Up to 3 days } & Count & 22 & 15 & 37 \\
\hline & $\%$ & $55 \%$ & $26.8 \%$ & $38.5 \%$ \\
\hline \multirow[t]{2}{*}{4 to 7} & Count & 3 & 5 & 8 \\
\hline & $\%$ & $7.5 \%$ & $8.9 \%$ & $8.3 \%$ \\
\hline \multirow[t]{2}{*}{8 to 15} & Count & 4 & 9 & 13 \\
\hline & $\%$ & $10 \%$ & $16.1 \%$ & $13.5 \%$ \\
\hline \multirow[t]{2}{*}{16 to 30} & Count & 9 & 21 & 30 \\
\hline & $\%$ & $22.5 \%$ & $37.5 \%$ & $31.4 \%$ \\
\hline \multirow[t]{2}{*}{$>30$ days } & Count & 2 & 6 & 8 \\
\hline & $\%$ & $5.0 \%$ & $10.7 \%$ & $8.3 \%$ \\
\hline \multirow[t]{2}{*}{ Total } & Count & 40 & 56 & 96 \\
\hline & $\%$ & $100 \%$ & $100 \%$ & $100.0 \%$ \\
\hline Chi-Square test & Value & $\mathrm{df}$ & $\begin{array}{l}\mathrm{P} \\
\text { value }\end{array}$ & \multirow{2}{*}{ Significant } \\
\hline $\begin{array}{l}\text { Pearson Chi- } \\
\text { square }\end{array}$ & 8.100 & 4 & 0.088 & \\
\hline
\end{tabular}

Table 6 shows association of NICU stay of neonates between two groups.

The mother who were not undergone cerclage, there were 27 neonates who required more than 15 days NICU stay compare to 11 neonates of those were undergone cerclage (Statistically not significant $\mathrm{p}=0.088$ ).

Table 7: Association of neonatal complications among study group and control group.

\begin{tabular}{|c|c|c|c|c|}
\hline \multirow{2}{*}{$\begin{array}{l}\text { Neonatal } \\
\text { complication }\end{array}$} & & \multicolumn{2}{|c|}{ Cerclage } & \multirow{2}{*}{ Total } \\
\hline & & Yes & No & \\
\hline \multirow[t]{2}{*}{ Yes } & 45 & 67 & 112 & 45 \\
\hline & $45.0 \%$ & $67 \%$ & $56.0 \%$ & $45.0 \%$ \\
\hline \multirow[t]{2}{*}{ No } & 55 & 33 & 88 & 55 \\
\hline & $55.0 \%$ & $33 \%$ & $44.0 \%$ & $55.0 \%$ \\
\hline \multirow[t]{2}{*}{ NA } & 100 & 100 & 200 & 100 \\
\hline & $100 \%$ & $100 \%$ & $100 \%$ & $100.0 \%$ \\
\hline \multirow[t]{2}{*}{ Total } & 100 & 100 & 200 & 100 \\
\hline & $100 \%$ & $100 \%$ & $100 \%$ & $100.0 \%$ \\
\hline Chi-Square test & Value & df & $\begin{array}{l}P \\
\text { value }\end{array}$ & \multirow{3}{*}{ Significant } \\
\hline $\begin{array}{l}\text { Pearson Chi- } \\
\text { square }\end{array}$ & 9.810 & 1 & 0.001 & \\
\hline Fisher's exact test & & & 0.002 & \\
\hline
\end{tabular}

Table 7 shows association of neonatal complications between two groups.

The mother who were not undergone cerclage, there were 67 neonates who had neonatal complications compare to 45 neonates of those were undergone cerclage. (Statistically significant $\mathrm{p}=0.001$ ). 
Table 8: Number of neonatal complications in study group and control group.

\begin{tabular}{|llll|}
\hline \multirow{2}{*}{ Neonatal complications } & \multicolumn{2}{l}{ Cerclage } & \multirow{2}{*}{ Total } \\
\hline Hypoglycaemia & Yes & No & \\
\hline Hyperbilirubinemia & 5 & 5 & 10 \\
\hline Hypothermia & 4 & 14 & 18 \\
\hline Low birth weight & 2 & 1 & 3 \\
\hline Respiratory distress & 30 & 31 & 61 \\
\hline Sepsis & 7 & 15 & 22 \\
\hline Twin to twin transfusion & 10 & 16 & 26 \\
\hline Hypoxia induced Encephalopathy & 0 & 2 & 2 \\
\hline Chi-square test & 0 & 1 & 1 \\
\hline Pearson Chi-square & Value & df & P value \\
\hline P value: Significant & 8.401 & 7 & 0.299 \\
\hline
\end{tabular}

$P$ value: Significant

Table 8 shows association of neonatal complications between two groups.

Overall the low birth weight was most common complications among all neonates. There is no statistically significant association between two groups. $(\mathrm{p}=0.299)$.

Table 9: Comparison of perinatal mortality in study group and control group.

\begin{tabular}{|llll|}
\hline \multirow{2}{*}{ Perinatal mortality } & \multicolumn{2}{l|}{ Cerclage } & \multirow{2}{*}{ Total } \\
\hline Macerated Still Birth & Yes & No & \\
\hline Fresh Still Birth & 1 & 3 & 4 \\
\hline Neonatal Death & 0 & 2 & 2 \\
\hline Chi-square test & 4 & 6 & 10 \\
\hline Pearson Chi-square & Value & df & P value \\
\hline P value: Significant & 1.388 & 2 & 0.512 \\
\hline
\end{tabular}

Table 9 shows association between two groups related to perinatal mortality.

It is more in women not undergone cerclage than women undergone cerclage. (Statistically not significant $\mathrm{p}=0.512$ ).

Table 10: Distribution of method of conception with respect to cerclage.

\begin{tabular}{|lllll|}
\hline \multirow{2}{*}{$\begin{array}{l}\text { Method of } \\
\text { conception }\end{array}$} & \multicolumn{4}{c|}{ Cerclage } \\
\hline Yes & Count & 30 & No & Total \\
\hline & $\%$ & $60 \%$ & $84.0 \%$ & 72 \\
\hline No & Count & 20 & 8 & 28 \\
\hline & $\%$ & $40 \%$ & $16.0 \%$ & $28.0 \%$ \\
\hline NA & Count & 50 & 50 & 100 \\
\hline & $\%$ & $100 \%$ & $100 \%$ & $100.0 \%$ \\
\hline Total & 100 & 100 & 200 & 100 \\
\hline & $100 \%$ & $100 \%$ & $100 \%$ & $100.0 \%$ \\
\hline Fisher's exact test & & & 0.002 & \\
\hline
\end{tabular}

\section{DISCUSSION}

The study included 100 cases out of which 50 were undergone MacDonald's cervical cerclage (forming "Study group") and the remaining 50 were not undergone cerclage (forming "Control group").

In present study, Mean gestational age at the time of cerclage was $17.6 \%$. The gestational age at the time of cervical cerclage was not found to be related to the perinatal outcome in study group.

Table 10: Gestational age at cervical cerclage.

\begin{tabular}{|ll|}
\hline Authors & $\begin{array}{l}\text { Mean gestational age at } \\
\text { cervical cerclage (weeks) }\end{array}$ \\
\hline Rebarber A et al $^{11-12}$ & 13.1 \\
\hline Aguilera $\mathrm{M} \mathrm{et} \mathrm{al}^{13}$ & 20.6 \\
\hline Liddiard A et al $^{14}$ & 21.0 \\
\hline
\end{tabular}

\section{Operative complications}

Aguilera $\mathrm{M}$ et al, There were no complications related to the procedure of cerclage. ${ }^{13}$

In present study, there were no operative complications noted, signifying its safety.

\section{Gestation age at delivery}

Liddiard A et al, Mean gestational age at delivery in group of women undergone cervical cerclage was 35 weeks. $^{14}$

Dor J, Preterm vaginal delivery were $45.4 \%$ in women undergone cerclage compare to $47.8 \%$ in women not undergone cerclage. ${ }^{15}$

Kunsch $\mathrm{U}$ et al, Out of women undergone cervical cerclage $100 \%$ delivered after 34 weeks whereas $17 \%$ delivered after 34 weeks in women not undergone cerclage. $^{16}$

Aguilera $\mathrm{M}$ et al, Out of women undergone cervical cerclage $61.5 \%$ delivered after 30 weeks, $30.8 \%$ after 32 weeks and $23 \%$ before 24 weeks of gestation. ${ }^{13}$

Collins A et al, Out of women undergoing cervical cerclage $6 \%$ delivered before 30 weeks, $13 \%$ delivered before 34 weeks. ${ }^{17}$

Rebarber et al, Women undergone cervical cerclage had mean gestational age at delivery of 33.5 weeks. ${ }^{11,12}$

In present study, mean gestational age at delivery for study population was 34.2 weeks, for Women undergone cerclage was 35.3 weeks and for women not undergone 
cerclage was 33.2 weeks. Also, women undergone cerclage and delivering after 37 weeks of gestation were $32 \%$ whereas women not undergone cerclage and delivering after 37 weeks of gestation were $8 \%$. This signifies that women not undergone cerclage had more number of preterm births.

\section{Mode of delivery}

Normon JE et al, In women with twin gestation with placebo therapy LSCS rate was $59.2 \%$ and instrument delivery rate was $8.8 \%$ whereas in study group with women with twin gestation undergoing progesterone support therapy it was $64.4 \%$ and $12 \%$ respectively. ${ }^{18}$

In present study, the women who had undergone cerclage had LSCS rate of $86 \%$ compare to $72 \%$ of that of women not undergone cerclage.

\section{Birth weight}

Kunsch U et al, In women undergone cervical cerclage $91 \%$ neonates had more than $2 \mathrm{Kg}$ birth weight and $76 \%$ neonates of women not undergone cerclage had birth weight of more than $2 \mathrm{Kg} .{ }^{16}$

Weekes ARL et al, The mean birth weight of neonates was $2.55 \mathrm{Kg}$ in women undergone cerclage and was $2.44 \mathrm{Kg}$ in women not undergone cerclage. ${ }^{19}$

In present study, the mean birth weight of neonates was $1.825 \mathrm{Kg}$ in study population, was $1.976 \mathrm{Kg}$ in women undergone cerclage and was $1.673 \mathrm{Kg}$ in women not undergone cerclage. In women undergone cervical cerclage $53 \%$ neonates had more than $2 \mathrm{Kg}$ birth weight and $31 \%$ neonates of women not undergone cerclage had birth weight of more than $2 \mathrm{Kg}$. There was statistically significant difference between two groups.

\section{APGAR score}

In present study, Mean APGAR score for study population was 8 , for women undergone cerclage was 8.5 and for women not undergone cerclage was 7.5. There was statistically significant difference between two groups.

\section{NICU admission}

Norman JE et al, In women with twin gestation with placebo therapy $32 \%$ neonates required NICU admission whereas $33.8 \%$ neonates of study group required NICU admission. ${ }^{18}$

In present study, in women undergone cerclage $45 \%$ neonates required NICU admission whereas in women not undergone cerclage $67 \%$ neonates required cerclage and overall $56 \%$ neonates required NICU admission. There was statically significant difference between two groups.

\section{NICU stay}

Norman JE et al, in women with twin gestation with placebo therapy mean NICU stay for neonates was 8.7 days whereas for neonates of study group it was 7.5 days. $^{18}$

In present study, in women undergone cerclage mean NICU stay for neonates was 4 days whereas in women not undergone cerclage it was 7 days and overall it was 6.1 days.

\section{Perinatal morbidity and mortality}

Liddiard A et al, 1 neonatal death occurred in 116 patients who undergone cerclage. ${ }^{14}$

Dor $\mathrm{J}$ et al, in women undergone cerclage neonatal death were $18.2 \%$ compare to $15.2 \%$ in women not undergone cervical cerclage. ${ }^{15}$

Kunsch $U$ et al, There was no perinatal mortality in women undergone cerclage whereas 1 neonatal death was there in women not undergone cerclage. ${ }^{16}$

Norman JE et al, There were 8 neonatal deaths and 6 intrauterine deaths in study group compare to 6 neonatal deaths and 4 intrauterine deaths. ${ }^{18}$

Weekes ARL et al, in women undergone cerclage perinatal death were 8 out of 120 compare to 3 out of 74 in women not undergone cerclage. ${ }^{19}$

In women undergone cerclage there were 4 neonatal deaths and 1 macerated still birth. In women not undergone cerclage there were 6 neonatal deaths, 2 fresh still births and 3 macerated still births. There was significantly increased perinatal mortality in women not undergone cerclage.

\section{CONCLUSION}

In spite of close vigilance, preterm birth in twin gestation is common and unpredictable. One of the factors of preterm birth in twin gestation is uterine overdistention. This can be prevented by cervical cerclage. My study supports this hypothesis.

Elective cervical cerclage appear to have low complication rates and high live-birth rates. MacDonald's cervical cerclage can prolong the gestational period. Hence, it is helpful in decreasing the incidences of premature neonate, low birth weight neonate and ultimately its further consequences. Neonates with very premature birth should be managed in the NICU where they can be closely monitored and treated. 
MacDonald's cervical cerclage is completely safe if done by skilled person. So offering prophylactic MacDonald's cervical cerclage in twin gestation between 16 and 20 weeks will not harm the women.

It is difficult to predict those who may require cervical cerclage although all multiple pregnancies are at high risk. Cerclage should be considered an option for patients with twin pregnancies in the second trimester.

Pathogenesis of preterm birth is multifactorial in twin gestation. Hence prophylactic cervical cerclage is not only solution for preventing preterm birth in twin gestation. But according to my study results, it's one of the tools to prevent preterm birth in twin gestation.

Funding: No funding sources

Conflict of interest: None declared

Ethical approval: Not required

\section{REFERENCES}

1. Alexander G, Kogan M, Martin J, Papiernik E. What are the fetal growth patterns of singletons, twins, and triplets in the United States? Clinical Obstetrics and Gynecology. 1998;41(1):114-25.

2. Weiner GM. Problems associated with premature birth. Working with the team. In: Zaichkin J. Newborn Intensive Care: What Every Parent Needs to Know. Ann Arbor, Mich.: Sheridan Books; 2009:223.

3. Mandy GT. Long-term complications of the premature infant. http://www.uptodate.com/home/index.html. Accessed Nov. 30, 2011.

4. Barfield WD. Late preterm infants. http://www.uptodate.com/home/index.html. Accessed Nov. 18, 2011.

5. Hovi P. Glucose regulation in young adults with very low birth weight. The New England Journal of Medicine. 2007;356:2053.

6. Blencowe H, Cousens S, Oestergaard M, Chou D, Moller AB, Narwal R. National, regional and worldwide estimates of preterm birth. The Lancet, June 2012;379(9832):2162-72.

7. Goldenberg RL, Hauth JC, Andrews WW. Intrauterine infection and preterm delivery. New England Journal of Medicine. 2000;342(20):1500-7.

8. Hillier SL, Nugent RP, Eschenbach DA. Association between bacterial vaginosis and preterm delivery of a low-birthweight infant. The vaginal infections and prematurity study group. New England Journal of Medicine. 1995;333(26):1737-42.

9. Iams JD, Goldenberg RL, Meis PJ. The length of the cervix and the risk of spontaneous premature delivery. National Institute of Child Health and Human Development Maternal Fetal Medicine Unit Network. New England Journal of Medicine. 1996;334(9):567-72.

10. Fox NS, Chervenak FA. Cervical cerclage: a review of the evidence. Obstet Gynecol Surv. 2008;63(1):58-65.

11. Fox NS, Rebarber A, Roman AS, Klauser CK, Saltzman DH. Association between second-trimester cervical length and spontaneous preterm birth in twin pregnancies. J Ultrasound Med. 2010;3:1733-9.

12. Rebarber A, Bender S, Silverstein M, Saltzman DH, Klauser CK, Fox NS. Outcomes of emergency or physical examination-indicated cerclage in twin pregnancies compared to singleton pregnancies. Eur J Obstet Gynecol Reprod Biol. 2014;173:43-7.

13. Aguilera M, Ramin K. Emergency Cerclage Placement in Multifetal Pregnancies with a Dilated Cervix and Exposed Membranes: Case Series. AJP Rep. 2013;3(1):1-4.

14. Liddiard A. Elective and emergency cervical cerclage and immediate pregnancy outcomes: a retrospective observational study. JRSM Short Rep. 2011;2(11):91.

15. Dor J. Elective Cervical Suture of Twin Pregnancies Diagnosed Ultrasonically in the First Trimester following Induced Ovulation. Gynecol Obstet Invest 1982;13:55-60.

16. Künsch U, Hochuli E. Cerclage and tocolysis in twin pregnancies. Geburtshilfe Frauenheilkd. 1984;44(4):249-51.

17. Collins A, Hezelgrave N, Shennan A. Cerclage use in twins with and without a prior preterm birth", Arch Dis Child Fetal Neonatal Ed. 2014;99 Suppl 1:A89-92.

18. Norman JE. Progesterone for the prevention of preterm birth in twin pregnancy (STOPPIT): a randomised, double-blind, placebo-controlled study and meta-analysis. Lancet 2009;373:2034-40.

19. Weekes ARL. The relative efficacy of bed rest, cervical suture, and no treatment in the management of twin pregnancy. BJOG. 1977;84(3):161-4.

Cite this article as: Chavan MS, Jassawalla MJ. Comparison of perinatal outcome in twin pregnancy with and without cervical cerclage. Int J Reprod Contracept Obstet Gynecol 2016;5:3924-30. 